\title{
INFLUENCE OF NITRATES, PHOSPHATE, SULPHATE AND SALTS OF Ca, Mg AND K, ON HYDROGEL HYDRATATION CAPACITY
}

\author{
Orlando Sílvio Caires Neves ${ }^{2 *} \odot$, Igor Glaeser da Rocha ${ }^{\circledR} \odot$, Eduarda Demari Avrella ${ }^{\circ}$,

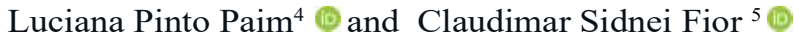

\footnotetext{
${ }^{1}$ Received on 02.09.2019 accepted for publication on 22.11.2019.

${ }^{2}$ Universidade Federal da Bahia, Instituto Multidisciplinar em Saúde, Vitória da Conquista, BA-Brasil. E-mail: <orlandoscn@gmail.com>. ${ }^{3}$ Universidade Federal do Rio Grande do Sul, Programa de Pós-Graduação em Agronomia, Porto Alegra, RS-Brasil. E-mail: <igorglaeser@ yahoo.com.br>.

${ }^{4}$ Universidade Federal do Rio Grande do Sul, Programa de Pós-Graduação em Fitotecnia, Porto Alegra, RS-Brasil. E-mail: < dudademari@ hotmail.com> and <lucianappaim@bol.com.br>.

${ }^{5}$ Universidade Federal do Rio Grande do Sul, Faculdade de Agronomia, Porto Alegra, RS-Brasil. E-mail: <csfior@ufrgs.br>

*Corresponding author.
}

\begin{abstract}
Hydrogel hydration capacity in solution was evaluated at different levels of electrical conductivity (EC) using nitrate, phosphates, sulfates, and salts of calcium, potassium and magnesium. Four sequential experiments were performed using potassium polyacrylate copolymer. The first experiment aimed to determine the lowest hydrogel dose, at which occur maximum deionized water absorption. The test was assembled in a completely randomized design with six hydrogel doses $\left(1,2,4,6,8\right.$ and $\left.10 \mathrm{~g} \mathrm{~L}^{-1}\right)$ and four replicates. The second experiment consisted of testing the sucrose P.A. doses $(0,1,2,4$ and $6 \%)$ in order to evaluate the change in osmotic potential of the solution on hydrogel hydration. The third and fourth studies were carried out in a complete randomized design, using a $6 \times 3 \times 2$ factorial scheme with four replicates. For the third experiment, the factors were six levels of EC $\left(0 ; 0.25 ; 0.50 ; 1.00 ; 1.50\right.$ and $\left.2.00 \mathrm{mS} \mathrm{cm}^{1}\right)$ increased by the addition of three anions $\left(\mathrm{NO}_{3}{ }^{-} ; \mathrm{PO}_{4}{ }^{3-}\right.$ and $\left.\mathrm{SO}_{4}{ }^{2-}\right)$ along with counter-ions $\mathrm{Ca}^{++}$and $\mathrm{K}^{+}$. For the fourth experiment, the same six levels of EC were achieved by adding the three cations $\left(\mathrm{Ca}^{++}, \mathrm{Mg}^{++}\right.$and $\left.\mathrm{K}^{+}\right)$, along with the counter-ions $\mathrm{Cl}^{-}$and $\mathrm{SO}_{4}{ }^{2-}$. Hydration capacity of the hydrogel decreases when the ionic concentration of the solution increases and the reduction of the osmotic potential through the addition of sucrose does not interfere in its swelling capability. Anions and cations in the solution negatively influence the process of the hydrogel hydration. The most pronounced effect is for those with higher valence.
\end{abstract}

Keywords: Hydroretenctor; Ions; Polyacrylate.

\section{INFLUÊNCIA DE NITRATOS, FOSFATOS, SULFATOS E SAIS DE Ca, Mg E K, SOBRE A CAPACIDADE DE HIDRATAÇÃO DO HIDROGEL}

RESUMO - A capacidade de hidratação do hidrogel em solução foi avaliada em diferentes níveis de condutividade elétrica (CE), usando nitratos, fosfatos, sulfatos e sais de cálcio, magnésio e potássio. Foram realizados quatro experimentos sequenciais, utilizando-se um copolímero de poliacrilato de potássio. O primeiro ensaio objetivou determinar a menor dose de hidrogel, na qual se obtivesse a máxima absorção de água deionizada e foi montado num delineamento inteiramente casualizado, com seis doses de hidrogel $\left(1,2,4,6,8\right.$ e $\left.10 \mathrm{~g} \mathrm{~L}^{-1}\right)$ e quatro repetições. $\mathrm{O}$ segundo estudo, montado num delineamento experimental inteiramente casualizado, com quatro repetições, consistiu em testar doses de sacarose P.A. (0, 1, 2, 4 e $6 \%$ ), afim de avaliar a alteração no potencial osmótico da solução sobre a hidratação do hidrogel. O terceiro e o quarto estudos foram desenvolvidos em delineamento inteiramente casualizado, num esquema fatorial $6 \times 3 \times 2$, com quatro repetições. Para o terceiro estudo, os fatores constituíram de seis níveis de CE $\left(0 ; 0,25 ; 0,50 ; 1,00 ; 1,50\right.$ e $\left.2,00 \mathrm{mS} \mathrm{cm}^{-1}\right)$, elevada pela

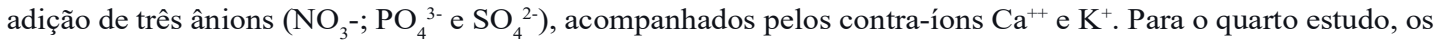
mesmos seis níveis de $\mathrm{CE}$ foram atingidos pela adição de três cátions $\left(\mathrm{Ca}^{++}, \mathrm{Mg}^{++}\right.$e K $\left.\mathrm{K}^{+}\right)$, acompanhados pelos contra-íons $\mathrm{Cl}^{-}$e $\mathrm{SO}_{4}^{2-}$. A capacidade de hidratação do hidrogel reduz com a elevação da concentração iônica da solução e que a redução do potencial osmótico, pela adição de sacarose, não interfere na sua capacidade

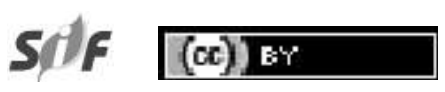

Revista Árvore 2020;44:e4408 http://dx.doi.org/10.1590/1806-908820200000008 
de intumescimento. Os ânions e cátions em solução influenciam negativamente no processo de hidratação do hidrogel, sendo o efeito mais pronunciado para aqueles de maior valência..

Palavras-Chave: Hidroretentor; Íons; Poliacrilato.

\section{INTRODUCTION}

Potassium polyacrylate copolymer is a molecule with great capacity for water absorption due to its particular conformation provided by the presence of potassium salts. In contact with water, the carboxylic groups of the polymer dissociate into negatively charged carboxylic ions. This process causes the enrichment of molecular chains with equally charged ionic groups, with a tendency to repel each other. As a result, the volume of the polymer cavity is incremented, hence greater water storage. The nature of the arrangement of molecules gives this material a granular shape when dried and, when hydrated, the granules are dilated into gel particles (Prevedello and Balena, 2000; Navroski et al., 2016a).

Studies aimed at reducing the depth and frequency of irrigation in the production of seedlings of the species used in farming and forestry by combining substrates with synthetic hydrochloride polymers are more and more frequent (Saad et al., 2009). The hydrogel has the potential to absorb 150 to 400 times its dry mass, so it can be used to increase substrate water storage capacity, therefore, minimizing the issues associated with irregular and deficient water availability (Marques et al., 2013).

When hydroretentor polymers are incorporated into the cultivation substrates, the results vary in responses to water retention and consumption characteristics and plant response (Gervásio and Frizone, 2004). According to these authors, the frequently used copolymers have a high absorption capacity in distilled water, however, they are physically unstable in the presence of salts due to the few and weak crosslinkings. Despite this observation, there are few studies that verify comprehensively the effects of salts on the hydration potential of hydroretentor polymers.

Overall, the conclusions on the use of the hydrogel are large and do not consider the chemical characteristics of the solution or substrate to be used. Hydrogel added to the substrate supports water retention and enhances the attributes involving storage and supply of water to the plants (Navroski et al., 2016b).

Electrical conductivity (EC) is a simple and low cost parameter for its determination (Mota et al., 2013).
It measures the resistance to the passage of electric current between the electrodes submitted to a solution, where ionic solutes (cations and anions) are found. The higher the concentration of dissolved salts, the higher the value of EC, thus, it is an indirect measure of the ionic concentration of the solution (Schmitt et al., 2016).

Despite the existence of several scientific papers reporting the use of hydrogel as an alternative technique for agriculture, most of those studies are solely directed to the effects of the polymer on increasing water retention capacity. Regarding the interactions between polymer and nutrients, either in solution or substrates, the information is very limited and generic. Therefore, the objective of this work was to evaluate the change in the electrical conductivity in the solution caused by the addition of nitrates, phosphates, sulfates and calcium, magnesium and potassium salts on hydrogel hydration capacity.

\section{MATERIAL AND METHODS}

Four sequential experiments were carried out in 2019 at the Horticulture Biotechnology Laboratory/ Department of Horticulture and Forestry, at the Federal University of Rio Grande do Sul (UFRGS), Porto Alegre, state of Rio Grande do Sul. A water insoluble potassium polyacrylate $\left(\mathrm{K}_{2} \mathrm{~S}_{2} \mathrm{O}_{8}\right)$ copolymer with particle size ranging from 0.1 to $0.9 \mathrm{~mm}$, mass density of 580 to $800 \mathrm{~g} \mathrm{~L}^{-1}$, cation exchangeable capacity of 3.100 mmol dm $\mathrm{dm}^{-3}$ and $180 \%$ water retention capacity was used in all experiments (according to technical information provided by the manufacturer).

The first test was developed in order to determine the lowest hydrogel dose, in which the maximum absorption of the deionized water would be obtained, and then used in the other studies. The experiment was assembled in a completely randomized design with six doses of hydrogel $\left(1,2,4,6,8\right.$ and $\left.10 \mathrm{~g} \mathrm{~L}^{-1}\right)$ and four replications. The hydrogel was hydrated with deionized water and stored in 50-ml falcon tubes for two hours. After this rest period, the hydrogel was drained under atmospheric pressure through a $10-\mathrm{mm}$ diameter opening in the base of the falcon tube, blocked by a thin layer of cotton to allow only passage of water and avoid hydrated

Revista Árvore 2020;44:e4408 
hydrogel particles. The drained volume was measured after 24 and 48 cumulatively hours. At the end, besides the volume, the $\mathrm{pH}$ was also measured with the aid of a digital pH-meter and the electrical conductivity of the leachate using a conductivity meter. Water withheld by the hydrogel was calculated and the result expressed as a percentage, which was the difference between the initial volume of water added for hydration and the drained volume. Retention efficiency was calculated considering the mass $(\mathrm{g})$ of the water retained by the hydrogel mass $(\mathrm{g})$.

The second experiment consisted of testing the most efficient dose of water absorbed by the hydrogel obtained in the first experiment $\left(4 \mathrm{~g} \mathrm{~L}^{-1}\right)$ in solutions with sucrose P.A. doses $(0,1,2,4$ and $6 \%)$ in order to evaluate the change in the osmotic potential of the solution upon hydrogel hydration. The experimental design was completely randomized, with five sucrose doses and four replications.

Sucrose was dissolved in deionized water and the solution was placed in 50-ml falcon tubes with the addition of $4 \mathrm{~g} \mathrm{~L}^{-1}$ hydrogel. After the two-hour rest period, the hydrogel was drained under atmospheric pressure. The drained volume was measured after 48 hours. At the end, similarly to the first test, the $\mathrm{pH}$ and the electrical conductivity of the leachate were also measured, in addition to the volume. Water held by the hydrogel was calculated and the result expressed as a percentage, which was the difference between the initial volume of the water added for hydration and the drained volume. Holding efficiency was calculated considering the mass $(\mathrm{g})$ of water retained by the hydrogel mass $(\mathrm{g})$.

The third and fourth experiments were carried out in a completely randomized design, in a $6 \times 3 \times 2$ factorial scheme, with four replications.

For the third experiment, the factors consisted of six levels of electrical conductivity $(0.0 ; 0.25 ; 0.50$; $1.00 ; 1.50$ and $2.00 \mathrm{mS} \mathrm{cm}^{-1}$ ), raised by the addition of three anions $\left(\mathrm{NO}^{3-}, \mathrm{PO}_{4}^{3-}\right.$ and $\left.\mathrm{SO}_{4}^{2-}\right)$, which are followed by $\mathrm{Ca}^{++}$and $\mathrm{K}^{+}$counter-ions. The desired levels of electrical conductivity (EC) were achieved by preparing $0.1 \mathrm{~mol} \mathrm{~L}^{-1}$ standard solutions of calcium nitrate, potassium nitrate, calcium phosphate, potassium phosphate, calcium sulfate and potassium sulfate diluted in deionized water which was monitored using a conductivity meter until the desired level was achieved. In relation to the fourth experiment, it consisted of six levels of electrical conductivity $(0.0 ; 0.25 ; 0.50 ; 1.00$; 1.50 and $\left.2.00 \mathrm{mS} \mathrm{cm}^{-1}\right)$, increased by adding three cations $\left(\mathrm{Ca}^{++}, \mathrm{Mg}^{++}\right.$and $\left.\mathrm{K}^{+}\right)$, which are followed by $\mathrm{Cl}^{-}$ and $\mathrm{SO}_{4}^{2-}$ counter-ions. In order to achieve the desired electrical conductivity levels, $0.1 \mathrm{~mol} \mathrm{~L}^{-1}$ standard solutions of calcium chloride, magnesium chloride, potassium chloride, calcium sulfate, magnesium sulfate and potassium sulfate were prepared and diluted in deionized water, monitored with a conductivity meter until the desired level was achieved.

The solutions of each treatment, corresponding to the third and fourth experiments, were transferred to 50$\mathrm{ml}$ falcon tubes and $4 \mathrm{~g} \mathrm{~L}^{-1}$ of hydrogel were added.. After the two-hour hydration rest period, the hydrogel was drained under atmospheric pressure for 48 hours. The leachate volume was measured and the $\mathrm{pH}$ and electrical conductivity were analyzed. Water held by the hydrogel was calculated and the result expressed as a percentage of the difference between the initial volume of water added for hydration and the drained volume. Retention efficiency was calculated considering the mass $(\mathrm{g})$ of the water retained by the mass $(\mathrm{g})$ of the hydrogel.

The leachate obtained in the control treatment $\left(0.0 \mathrm{mS} \mathrm{cm} \mathrm{cm}^{-1}\right)$ was analyzed for quantification of the chemical composition derived only from the addition of the hydrogel.

For all experiments, the data were subjected to analysis of variance and, when significant, regression analyses were performed for quantitative factors, and Tukey test for comparison of means at 5\% of error probability when the factors were qualitative. The statistical software SISVAR, version 5.7 (Ferreira, 2018) was used.

\section{RESULTS}

Data on electrical conductivity, $\mathrm{pH}$ of the leachate and water retention at 24 and 48 hours in the first experiment showed significant effects at $1 \%$ error probability. The regression equations that best fit the results are shown in Figure 1. The coefficients of variation (CV) were $10.0 \%$ for the electrical conductivity; $0.9 \%$ for $\mathrm{pH} ; 1.37 \%$ for 24 -hour water holding and; $1.9 \%$ for 48-hour holding period.

Hydration of the hydrogel in deionized water is capable of raising the EC of the leachate in which the response to the hydration dose is linear and positive
Revista Árvore 2020;44:e4408 

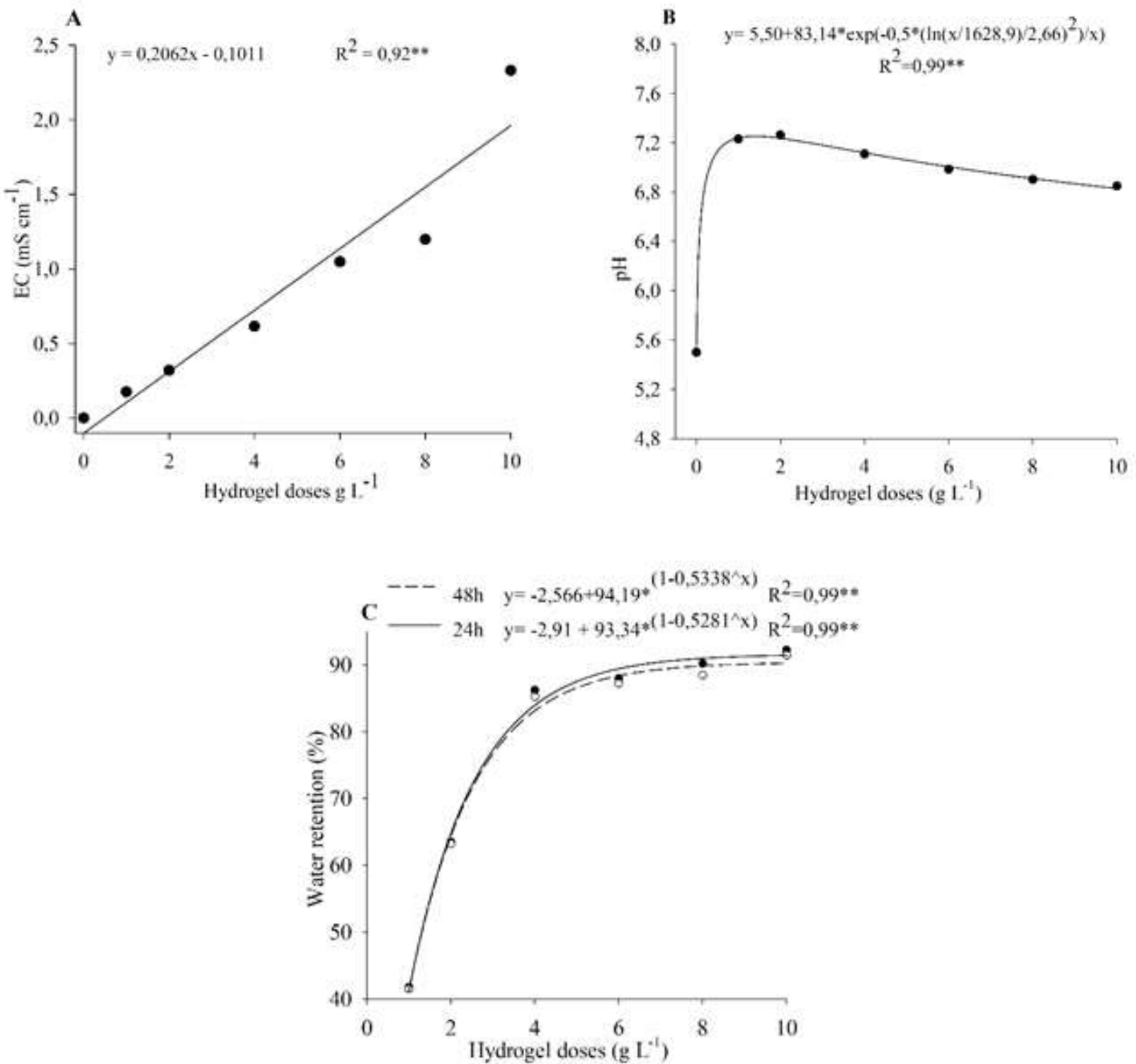

Figure 1 - Electrical conductivity of the leachate (A), $\mathrm{pH}(\mathrm{B})$ of leachate and water retention (C) as a function of hydrogel doses. $(* *)$ significant at $1 \%$ of the error probability..

Figura 1 - Condutividade elétrica do lixiviado $(\ddot{A})$, pH (B) do lixiviado e retenção de água $(C)$ em função de doses de hidrogel. (**) significativo a $1 \%$ de probabilidade de erro.

(Figure 1 A). Such behavior can be explained by the chemical composition of the copolymer used in the experiment (potassium polyacrylate), as, some of the potassium of the molecule composition becomes ionic during the hydration process.

The potential for release of chemical elements through the hydrogel over the hydration process can be inferred based on the increased electrical conductivity of the leachate combined to its chemical composition (Figure $1 \mathrm{~A}$ ). Thus, in addition to behaving as a hydroretentor, consideration should be given to releasing nutrient elements in the evaluation of the results obtained from hydrogel application when studying plant growth and mineral nutrition. In addition to potassium, it should be highlighted the important contribution of sodium and, to a lesser extent, $\mathrm{Ca}$ and $\mathrm{Mg}$ as the chemical

\section{Revista Árvore 2020;44:e4408}


composition (mg L-) of hydrogel leachate, hydrated in deionized water and obtained from the application of 4 $\mathrm{g} \mathrm{L}^{-1}$ dose of the copolymer was: $\mathrm{P}=0.6 ; \mathrm{K}=360.5$; $\mathrm{Ca}$ $=4.20 ; \mathrm{Mg}=3.5 ; \mathrm{S}=2.0 ; \mathrm{Cu}=0.00 ; \mathrm{Fe}=0.10 ; \mathrm{Mn}=$ $0.03 ; \mathrm{Zn}=0.04$ and $\mathrm{Na}=40.15$. The leachate $\mathrm{EC}$ was $0.69 \mathrm{mS} \mathrm{cm}^{-1}$. The addition of small doses of hydrogel in aqueous medium (up to approximately $2 \mathrm{~g} \mathrm{~L}^{-1}$ ) provides a considerable increase in $\mathrm{pH}$ values (Figure $1 \mathrm{~B}$ ). At doses of 1 and $2 \mathrm{~g} \mathrm{~L}^{-1}$, the $\mathrm{pH}$ values, adjusted by the regression equation, reached 7.3 and 7.2 , respectively, reduced to 6.8 at the $10 \mathrm{~g} \mathrm{~L}^{-1}$ dose. Despite being significant, values of $\mathrm{pH}$ behavior at all doses (hydrogel addition) were close to neutrality. Also, it is observed a rise in the $\mathrm{pH}$ of the leachate when the hydrogel was added, compared to the $\mathrm{pH}$ of the deionized water (5.5) used for hydration, although, in the presence of the polymer, the increase in the doses provided a slight but significant decrease in their values.

Water retention was evaluated at 24 and 48 hours after onset of the drainage (Figure $1 \mathrm{C}$ ) as a function of the applied doses of hydrogel. It is noteworthy that the retention potential did not differ significantly between the evaluation periods, therefore, indicating hydrogel stability after water absorption when subjected to atmospheric condition within the evaluated time interval.

The holding potential, which is represented by the percentage of water held by the hydrogel in relation to the total available deionized water, increased exponentially, especially up to the $4 \mathrm{~g} \mathrm{~L}^{-1}$ dose, with a small variation from this level (Figure $1 \mathrm{~W}$ ). In the assessment performed at 24-hour rest, the retention estimated by the equation was 47,90 and $96 \%$ for doses of 1, 4 and $10 \mathrm{~g} \mathrm{~L}^{-1}$, respectively. Thus, considering a medium initially free of ions and the product used in this study, the dose of $4 \mathrm{~g} \mathrm{~L}^{-1}$ hydrogel is efficient in holding water, and from it, the variation is not significant.

In relation to the results of the second experiment, it is observed that the reduction in the osmotic potential caused by the addition of sucrose does not interfere with the hydrogel water holding capacity $\left(p=0.5603^{\text {ns }}\right.$ and $\mathrm{CV}=3.9 \%$ ). Consequently, it also does not interfere with the efficiency of water absorption by the polymer/ copolymer $\left(\mathrm{p}=0.4193^{\mathrm{ns}}\right.$ and $\left.\mathrm{CV}=4.0 \%\right)$. In addition, the electrical conductivity, measured from the leachate, was not influenced by addition of sucrose $(p=0.9418 \mathrm{~ns}$ and $\mathrm{CV}=20.1 \%$ ), a behavior similar to that observed for $\mathrm{pH}$ values $(\mathrm{p}=0,2025 \mathrm{~ns}$ and $\mathrm{CV}=7.2 \%)$.
For the data obtained in the third experiment, the analysis of variance performed for the hydrogel efficiency $(\mathrm{CV}=3.76 \%)$ shows that the triple interaction (levels of electrical conductivity $\mathrm{x}$ anions $\mathrm{NO}_{3}^{-}, \mathrm{PO}_{4}{ }^{3-}$ and $\mathrm{SO}_{4}^{2-} \mathrm{x}$ against $\mathrm{Ca}^{++}$and $\mathrm{K}^{+}$counter-ions) was significant at the $1 \%$ error probability level. Thus, the increase in EC levels negatively influenced the efficiency of the hydrogel in retaining liquids (Figure 2). However, and particularly at higher EC levels, the reduction in efficiency is more pronounced when conductivity is changed by the association of anions with the $\mathrm{Ca}$ counter-ion and, to a lesser extent, by the association of anions with the counter-ion $\mathrm{K}$.

A significant performance of the anions in reducing the efficiency of the hydrogel is observed from the level of $0.25 \mathrm{mS} \mathrm{cm}^{-1}$, which is intensified with the increase in the levels of EC (Table 1). Regardless of the counter-ion, the most pronounced and significant effect in promoting hydrogel efficiency reduction was found in the following order: $\mathrm{PO}_{4}^{3-}>\mathrm{SO}_{4}{ }^{2-}>\mathrm{NO}_{3}-$.

Regardless of the anion and EC (except for the level $0.0 \mathrm{mS} \mathrm{cm}^{-1}$ ), the effect of $\mathrm{Ca}^{++}$on the solution is always more striking than that of $\mathrm{K}^{+}$, reducing hydrogel hydration efficiency (Table 1).

Considering only the nitrate anion and the highest EC level, its action combined with calcium is enhanced

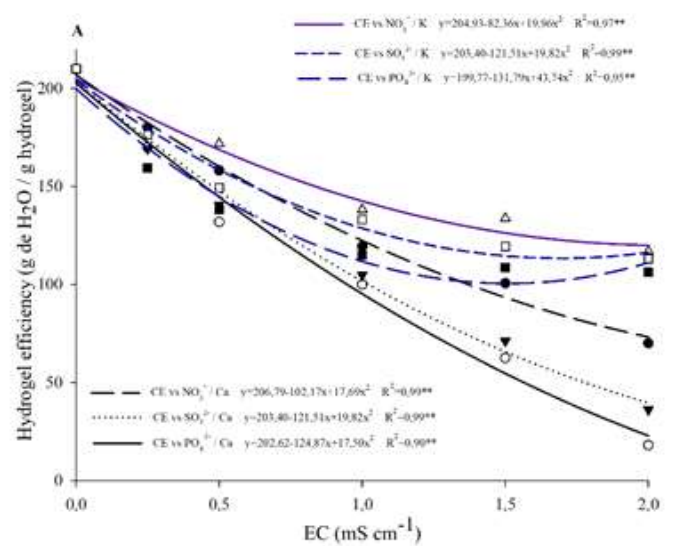

Figure 2 - Efficiency of water retention by hydrogel as a function of electrical conductivity (EC) levels within each ion and counter-ion. $(* *)$ significant at $1 \%$ of the error probability..

Figura 2 - Eficiência da retenção de água pelo hidrogel em função dos níveis da condutividade elétrica $(C E)$, dentro de cada íon e contra-ion. (**) significativo a $1 \%$ de probabilidade de erro.

\author{
Revista Árvore 2020;44:e4408
}

\section{silf}


Table 1 - Unfolding of the effect of anions within each counter-ion; of counter ions within each anion and levels of electrical conductivity (EC) on the hydrogel water retention efficiency $\left(\mathrm{g} \mathrm{H}_{2} \mathrm{O} / \mathrm{g}\right.$ hydrogel).

Tabela 1 - Desdobramento do efeito dos ânions, dentro de cadá contra-íon; dos contra-ions dentro de cada ânion e niveis de condutividade elétrica (CE), sobre a eficiência de retenção de água pelo hidrogel ( $\mathrm{g} \mathrm{H} \mathrm{H}_{2} \mathrm{O} / \mathrm{g}$ hidrogel).

\begin{tabular}{|c|c|c|c|c|c|c|c|}
\hline \multirow[b]{2}{*}{ Counter ion } & \multirow[b]{2}{*}{ Anion } & \multicolumn{6}{|c|}{. } \\
\hline & & 0.00 & 0.25 & 0.50 & 1.00 & 1.50 & 2.0 \\
\hline \multirow[t]{3}{*}{ Calcium } & $\mathrm{NO}_{3}^{-}$ & $210.00 \mathrm{Aa}$ & $180.00 \mathrm{Aa}$ & $158.12 \mathrm{Ba}$ & $119.37 \mathrm{Ba}$ & $100.62 \mathrm{Ba}$ & $\overline{70.00 \mathrm{Ba}}$ \\
\hline & $\mathrm{PO}_{4}^{3-}$ & $210.00 \mathrm{Aa}$ & $170.00 \mathrm{Ab}$ & $131.87 \mathrm{Ac}$ & $100.00 \mathrm{Bb}$ & $62.50 \mathrm{Bc}$ & $18.12 \mathrm{Bc}$ \\
\hline & $\mathrm{SO}_{4}^{2-}$ & $210.00 \mathrm{Aa}$ & $169.25 \mathrm{Ab}$ & $140.62 \mathrm{Bb}$ & $105.00 \mathrm{Bb}$ & $71.25 \mathrm{Bb}$ & $36.25 \mathrm{Bb}$ \\
\hline \multirow[t]{3}{*}{ Potassium } & $\mathrm{NO}_{3}^{-}$ & $210.00 \mathrm{Aa}$ & $177.50 \mathrm{Aa}$ & $171.87 \mathrm{Aa}$ & $138.12 \mathrm{Aa}$ & $133.75 \mathrm{Aa}$ & $116.87 \mathrm{Aa}$ \\
\hline & $\mathrm{PO}_{4}^{3-}$ & $210.00 \mathrm{Aa}$ & $159.37 \mathrm{Bb}$ & 138.12 Ac & $115.00 \mathrm{Ab}$ & $108.75 \mathrm{Ac}$ & $106.25 \mathrm{Ab}$ \\
\hline & $\mathrm{SO}_{4}^{2-}$ & $210.00 \mathrm{Aa}$ & 176.25 Aa & $149.37 \mathrm{Ab}$ & 133.12 Aa & $119.37 \mathrm{Ab}$ & $113.12 \mathrm{Aab}$ \\
\hline
\end{tabular}

Means followed by the same lowercase letter in the column within each counter-ion and; capital letters in the column for each counter-ion within the same anion do not differ from each other $(\mathrm{p} \leq 0.05)$ by the test of Tukey.

Médias seguidas da mesma letra minúscula na coluna, dentro de cada contra-íon e; letra maiúscula na coluna para cada contra-íon, dentro do mesmo ânion, não diferem entre si $(\mathrm{p} \leq 0,05)$ pelo teste Tukey.

by $160 \%$ in relation to potassium, although both have negative effects on the hydrogel swelling process (Table 1). When the anion is sulfate, the effect of calcium reaches $314 \%$ in relation to potassium, reaching $590 \%$ when associated with phosphate. Based on the results, it can be inferred that the higher the valence of the ion in the solution, regardless of whether it is action or anion, the lower the water holding by the hydrogel. The depreciating effect is intensified when its concentration is higher, which can be inferred by the EC in the medium.

For the data obtained in the fourth experiment, the analysis of variance performed for the hydrogel efficiency factor $(\mathrm{CV}=3.77 \%)$ revealed that the triple interaction (levels of electrical conductivity $\mathrm{X}$ cations $\mathrm{Ca}, \mathrm{Mg}$ and $\mathrm{K}$ X chloride ions and sulfate) was not significant ( $\mathrm{p} \geq$ 0.094). However, for all double interactions (electrical conductivity levels $\mathrm{X} \mathrm{Ca}, \mathrm{Mg}$ and $\mathrm{K}$ cations; electrical conductivity levels $\mathrm{X}$ chloride and sulfate counter-ions and; $\mathrm{Ca}, \mathrm{Mg}$ and $\mathrm{K}$ cations $\mathrm{x}$ chloride and sulfate counterions) the results were significant at $1 \%$ error probability.

At higher EC levels, the reduction in hydrogel efficiency is more perceptible when the conductivity is changed due to the addition of $\mathrm{Ca}$ and $\mathrm{Mg}$ salts and, to a lesser extent, $\mathrm{K}$ salts. At the EC level of $20.0 \mathrm{mS} \mathrm{cm}^{-1}$, hydrogel efficiency was 64, 75 and $120 \mathrm{~g}$ of retained water/g hydrogel for $\mathrm{Ca}, \mathrm{Mg}$ and $\mathrm{K}$ salts, respectively and at the control dose $\left.(0.0 \mathrm{mS} \mathrm{cm})^{-1}\right)$, the efficiency was $204 \mathrm{~g}$ of retained water/g of hydrogel (Figure $3 \mathrm{~A}$ ). From the $0.0 \mathrm{mS} \mathrm{cm}^{-1}$ level to the $2.0 \mathrm{mS} \mathrm{cm}^{-1}$ level, the $\mathrm{Ca}, \mathrm{Mg}$ and $\mathrm{K}$ salts provided a reduction in hydrogel efficiency of 70, 63 and 42\%, respectively.

Considering the chloride and sulfate counterions, it is observed that both negatively influence the hydration potential of the hydrogel, especially at higher concentrations, inferred by means of EC. Besides, the effect of sulfate is stronger (negatively) than that of chloride (Figure $3 \mathrm{~B}$ ).

At the EC level of $2.0 \mathrm{mS} \mathrm{cm}^{-1}$ the hydrogel efficiency was 94 and $77 \mathrm{~g}$ of retained water/g hydrogel, respectively, in solutions whose counter-ions were $\mathrm{Cl}^{-}$ and $\mathrm{SO}_{4}^{-2}$ (Figure $\left.3 \mathrm{~B}\right)$. At the control dose $\left(0.0 \mathrm{mS} \mathrm{cm}^{-1}\right)$, the efficiency was $204 \mathrm{~g}$ of retained water/g of hydrogel. Based on the results obtained in the experiment, it can be stated that the effect of higher valence portrayed in the literature for cations can also be used to explain the lower water holding capacity of the hydrogel when chloride and sulfate ions are compared.

No significant difference was found between $\mathrm{Ca}$, $\mathrm{Mg}$ and $\mathrm{K}$ salts on hydrogel efficiency up to the level of $0.25 \mathrm{mS} \mathrm{cm}^{-1}$, although all three interfere with the hydration process (Figure $03 \mathrm{C}$ ). From the level of 0.50 to $1.0 \mathrm{mS} \mathrm{cm}$, it is observed that the negative effects of $\mathrm{Ca}$ and $\mathrm{Mg}$ salts do not differ significantly and are more noticeable and significant than the effects of $\mathrm{K}$ salts. For solutions with electrical conductivity levels equal to or greater than $1.5 \mathrm{mS} \mathrm{cm} \mathrm{cm}^{-1}$, the negative and significant effect of salts is observed in the order $\mathrm{Ca}>$ $\mathrm{Mg}>\mathrm{K}$. The results obtained in this work point to the importance of knowing the EC medium/substrate before hydrogel application as this is an indirect measure of ionic concentration (Figure 3 ).

Statistical analysis revealed a significant difference between $\mathrm{Cl}^{-}$and $\mathrm{SO}_{4}^{-2}$ in the capacity to negatively interfere with hydrogel hydration, where the effect of sulfate was more pronounced than chloride (Table 2). Regarding the cations used in this experiment, all

Revista Árvore 2020;44:e4408 

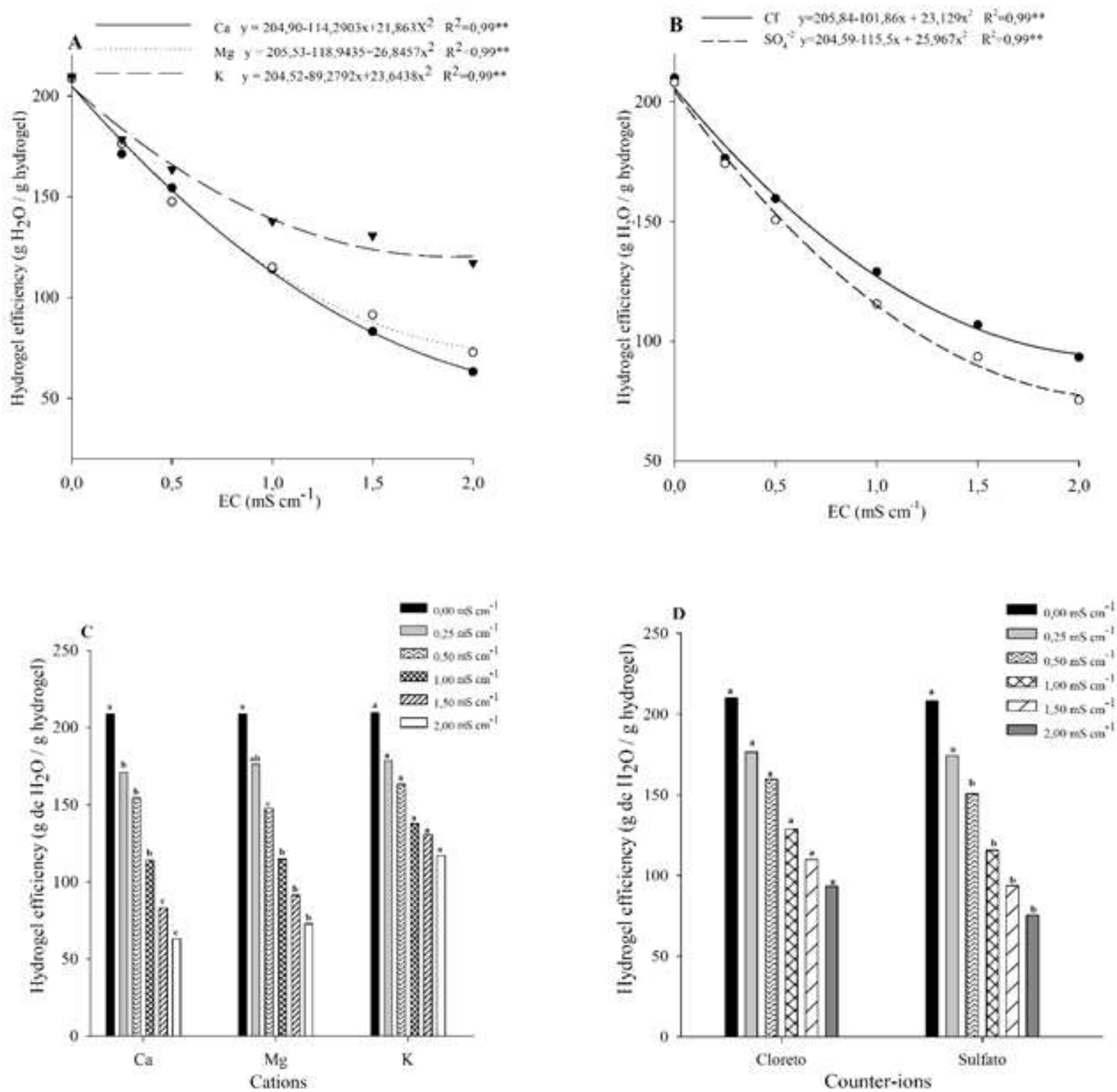

Figure 3 - Hydrogel efficiency as a function of electrical conductivity, changed by $\mathrm{Ca}, \mathrm{Mg}$ and $\mathrm{K}$ (A) salts; by the chloride and sulfate counter-ions (B); hydrogel efficiency at each electrical conductivity level as a function of $\mathrm{Ca}, \mathrm{Mg}$ and $\mathrm{K}(\mathrm{C})$ and; as a function of the counter ions $(\mathrm{D})$.

Figura 3 - Eficiência do hidrogel em função da condutividade elétrica, alterada pelos sais de $\mathrm{Ca}, \mathrm{Mg}$ e $\mathrm{K}(\mathrm{A})$; pelos contra-ions cloreto e sulfato (B); eficiência do hidrogel, em cada nível de condutividade elétrica, em função dos cátions Ca, $M g$ e K (C) e; em função dos contra-ions $(D)$

showed significant effects in reducing the hydration potential/efficiency of the hydrogel, especially when the concentration in solution is increased. In decreasing order, the cations that most contributed to the reduction of hydrogel efficiency in retaining the solution were, as follows: $\mathrm{Ca}^{++}>\mathrm{Mg}^{++}>\mathrm{K}^{+}$, when the counter-ion was sulfate and $\mathrm{Ca}^{++}=\mathrm{Mg}^{++}>\mathrm{K}^{+}$when the counter-ion was chloride (Table 2). 
Table 2 - Efficiency $\left(\mathrm{g} \mathrm{H}_{2} \mathrm{O} / \mathrm{g}\right.$ hydrogel) of the hydrogel based on the effect of $\mathrm{Ca}, \mathrm{Mg}$ and $\mathrm{K}_{\text {cations }}$ in $\mathrm{SO}_{4}^{2-}$ and $\mathrm{Cl}^{-}$counter-ions and the counter-ions within each cation.

Tabela 2 - Eficiência ( $\mathrm{g} \mathrm{H}_{2} \mathrm{O} / \mathrm{g}$ hidrogel) do hidrogel, a partir do desdobramento do efeito dos cátions $\mathrm{Ca}$, Mg e K, dentro dos contra-ion $\mathrm{SO}_{4}^{2-}$ e Cl e dos contra-ions, dentro de cada cátion.

\begin{tabular}{lcc}
\hline Counter-ion & Calcium & Magnesium \\
Chloride & $139.79 \mathrm{Ab}$ & $140.56 \mathrm{Ab}$ \\
Sulfate & $125.10 \mathrm{Bc}$ & $130.02 \mathrm{Bb}$ \\
\hline
\end{tabular}

Means followed by the same capital letter in the column do not differ from each other $(\mathrm{p} \leq 0.05)$ by the test of Tukey.

Means followed by the same lowercase letter on the line do not differ from each other $(\mathrm{p} \leq 0.05)$ by the test of Tukey.

Médias seguidas da mesma letra maiúscula na coluna, não difere entre si $(\mathrm{p} \leq 0,05)$ pelo teste Tukey.

Médias seguidas da mesma letra minúscula na linha, não difere entre si $(\mathrm{p} \leq 0,05)$ pelo teste Tukey.

\section{DISCUSSION}

It is reported in studies using hydrogel in crops of Eucalyptus dunnii (Navroski et al., 2015); Corymbia citriodora (Bernardi et al., 2012); Avena sativa (Scremin et al., 2017), among others that the application of hydrogel provides positive response to plant growth, as it promotes the availability of water and nutrients. However, they do not relate the availability of nutrients to the release of chemical elements from the copolymer chemical structure itself. The use of hydrogel in substrate composed of $30 \%$ coconut fiber, 35\% vermiculite and $35 \%$ rice husk for the cultivation of eucalyptus clonal seedlings did not increase the water holding by the substrate and plant growth (Tatagiba et al., 2019).

The application of hydrochloride polymers influences the characteristics of commercial substrates for forest seedling production, increasing $\mathrm{EC}$ and reducing $\mathrm{pH}$ (Navroski et al., 2016b). Even though the substrate has other chemical attributes, which may influence its buffering to the $\mathrm{pH}$ change, it is observed that the results obtained in the study are largely in line with those of this work.

When a hydrogel is placed in water or another swelling medium, its polymer chains interact with the medium, resulting in their expansion (Bortolin et al., 2012). When the networks no longer expand, the equilibrium state of the hydrogel is reached, that is, the moment when there are no more significant gravimetric variations. Thus, the non-variation in retention between 24 and 48 hours indicates the chemical stability of the polymer used in this study.

It is noteworthy that sucrose has no ability to conduct electric current. Also, the simple addition of the hydrogel at a dose of $4 \mathrm{~g} \mathrm{~L}^{-1}$ promoted the rise in the electrical conductivity of the medium by approximately $0.65 \mathrm{mS} \mathrm{cm}^{-1}$. This result confirms the hypothesis that the presence of salts, in ionic their form, interferes with hydrogel hydration capacity and cannot be attributed to the osmotic effect itself.

Hydrogel hydration capacity is drastically reduced when the swelling medium is changed from distilled water to ion-containing solution (Bortolin et al., 2012). When the hydrogel is immersed in a solution containing ions, local interactions may occur between hydroxyl groups and salt counter-ions, which may induce the formation of ionic pairs (or ionic complexes). Consequently, possible electrostatic repulsions between chain segments are minimized, impairing localized expansion of hydrogel networks. In addition, under extreme conditions, hydrogel networks may contract, which contributes to lower water absorption due to decreased affinity with water molecules (Bortolin et al., 2016).

Both in the association of anions with $\mathrm{Ca}$ and $\mathrm{K}$, the most pronounced and negative effect of higher valence anions interfering with water absorption by the hydrogel is clear. At the maximum tested EC level (2.0 $\mathrm{mS} \mathrm{cm}{ }^{-1}$ ) for the calcium/nitrate, calcium/phosphate and calcium/sulfate combinations, the hydrogel solution retention efficiency was 73, 23 and $40 \mathrm{~g}$ of water/g of hydrogel, respectively. At this same EC level, for the potassium/nitrate, potassium/phosphate and potassium/ sulfate combinations, the hydrogel solution retention efficiency was 120,111 and $116 \mathrm{~g}$ of water/g of hydrogel, respectively.

From the lowest to the highest evaluated EC level, there was a percentage reduction by 89,81 and $65 \%$ in hydrogel efficiency when the association was calcium/phosphate, calcium/ sulfate and calcium/nitrate, respectively. For the potassium/phosphate, potassium/ sulfate and potassium/nitrate association, the reduction was 47,44 and $42 \%$, respectively.

Revista Árvore 2020;44:e4408 
It can be found in the literature that the high absorption potential of polymers when subjected to water saturation is not the same when mixed in culture media, either soil or substrate. Gervásio and Frizone (2004) concluded that the expansion of hydro-absorbent polymers is limited in the presence of saline solution and Bowman et al. (1990) found that the intensity of reduction in absorption is related to the valence of ions in the solution and that absorption is more affected in the presence of bivalent cations, so the addition of hydrogels is unlikely to significantly increase water retention capacity in substrates, particularly in intensive seedling production systems, where the fertilization levels are high.

Regardless of the salt used to change the electrical conductivity of the solution, the increase in EC levels negatively influence the efficiency of the hydrogel in retaining liquids. Bowman et al. (1990) observed that the hydration of three commercial polyacrylamide polymers in the presence of bivalent cations $\left(\mathrm{Ca}^{++}\right.$and $\left.\mathrm{Mg}^{++}\right)$ and monovalent cations $\left(\mathrm{K}^{+}\right.$and $\left.\mathrm{NH}_{4}^{+}\right)$was reduced to approximately $10 \%$ and $20 \%$ of their maximum value, respectively. However, these authors made no mention to the counter-ions or the levels of electrical conductivity in the medium.

In a study conducted to investigate the water absorption process by polysaccharide hydrogels, Bortolin et al. (2012) observed that interactions between hydroxyl groups and counter-ions occur more strongly as the valence of counter-ion increases, i.e. : -O--- $\mathrm{X}^{+}$$<-(\mathrm{O})_{2}---\mathrm{X}^{2+}-<-(\mathrm{O})_{3}---\mathrm{X}^{3+}-$. In addition, the higher the valence of cations, the higher the positive charge density and, as a direct consequence, physical and/or chemical cross-linking points may be formed, therefore contributing to the increase in cross-linking density of hydrogels. In general, more strongly cross-linked hydrogel networks absorb less water due to their low flexibility.

\section{CONCLUSIONS}

Hydrogel hydration capacity decreases as ion concentration increases in the solution. Also, electrical conductivity is a good parameter for this prediction.

The reduction in the osmotic potential of the solution through the addition of sucrose does not interfere with the hydrogel swelling capacity.

Anions and cations in solution negatively influence the hydrogel hydration process. So, the most pronounced effect is found in the following order: $\mathrm{PO}_{4}{ }^{3-}>\mathrm{SO}_{4}{ }^{2-}>$ $\mathrm{NO}_{3}^{-}$, for anions and $\mathrm{Ca}^{++}>\mathrm{Mg}^{++}>\mathrm{K}^{+}$, for cations.

The effect of an ion in reducing hydrogel hydration capacity, at the same level of electrical conductivity, is enhanced by its counter-ion as the greater its valence.

\section{REFERENCES}

Bernardi MR, Sperotto Junior M, Daniel O, Vitorino ACT. Crescimento de mudas de Corymbia citriodora em função do uso de hidrogel e adubação. Cerne. 2012;18(1):67-74. doi: 10.1590/S010477602012000100009

Bortolin A, Aouada FA, Longo E, Mattoso LHC. Investigação do processo de absorção de água de hidrogéis de polissacarídeo: efeito da carga iônica, presença de sais, concentrações de monômero e polissacarídeo. Polímeros: Ciência e Tecnologia. 2012;22(4):311-317.doi: 10.1590/S010414282012005000046

Bortolin A, Serafim AR, Aouada FA, Mattoso LHC, Ribeiro C. Macro-and Micronutrient Simultaneous Slow Release from Highly Swellable Nanocomposite Hydrogels. J. Agric. Food Chem. 2016;64(16):31333140. doi: 10.1021 /acs.jafc. 6 b00190

Bowman DC, Evans RY, Paul JL. Fertilizer salts reduce hydration of polyacrylamide gels and affect physical properties of gel-amended container media. Journal of the American Society for Horticultural Science. 1990;115(3)382-386. doi: doi.org/10.21273/ JASHS.115.3.382

Ferreira DF. Programa computacional Sisvar-UFLA, versão $5.7 ; 2018$.

Gervásio ES, Frizzone JA. Caracterização físicohídrica de um condicionador de solo e seus efeitos quando misturado a um substrato orgânico. Irriga. 2004;9(2):94-105. doi: 10.15809/irriga.2004v9n2 p94-105

Marques PAA, Cripa MAM, Martizez EH. Hidrogel como substituto da irrigação complementar em viveiro telado de mudas de cafeeiro. Ciência Rural. 2013;43(1):1-7. doi: 10.1590/S010384782012005000129

Mota PRD, Fiorim ACR, Villas Bôas RL, Folegatti MV, Ludwig F, Silva ME. Condutividade elétrica da solução nutritiva e acúmulo de macro 
e micronutrientes no cultivo de crisântemo. Bragantia. 2013;72(1):81-89. doi:10.1590/S000687052013005000015

Navroski MC, Araújo MM, Reininger LRS, Muniz MFB, Pereira MO. Influência do hidrogel no crescimento e no teor de nutrientes das mudas de Eucalyptus dunnii. Floresta. 2015;45(2):315-328. doi: 10.5380/rf.v45i2.34411

Nacroski MC, Araujo MM, Cunha FS, Berghetti ALP, Pereira MO. Redução da adubação e melhoria das características do substrato com o uso do hidrogel na produção de mudas de Eucalyptus dunnii maiden. Ciência Florestal. 2016a;26(4):1155-1165. doi: 10.5902/1980509825106

Navroski MC, Araújo MM, Pereira MO, Fior CS. Influência do polímero hidroretentor nas características do substrato comercial para produção de mudas florestais. Interciência. 2016b;41(5):357361. Disponível em: http://www.redalyc.org/articulo. oa? $\mathrm{id}=33945552012$

Prevedello CL, Balena SP. Efeitos de polímeros hidrorretentores nas propriedades físico-hídricas de dois meios porosos. Revista Brasileira de Ciência do Solo. 2000;24(2):251-258. doi: 10.1590/S0100-

\section{2}

Saad JCC, Lopes JLW, Santos TA. Manejo hídrico em viveiro e uso de hidrogel na sobrevivência pósplantio de Eucalyptus urograndis em dois solos diferentes. Eng. Agríc. 2009;29(3):404-411. doi: $10.1590 /$ S0100-69162009000300007

Schmitt OJ, Andriolo JL, Schultz E, Lerner MA, Souza JM, Dal Picio M. Produção de estolhos de cultivares de morangueiro em função da condutividade elétrica da solução nutritiva. Hortic. Bras. 2016;34(2):294-301. doi: 10.1590/S0102053620160000200022

Scremin OB, Silva JAG, Mamman ATW, Mantai RD, Brezolin AP, Maroli A. Nitrogen efficiency in oat yield through the biopolymer hydrogel. Revista Brasileira de Engenharia Agrícola e Ambiental. 2017;21(6):379-385. doi: 10.1590/1807-1929/ agriambi.v21n6p379-385

Tatagiba SD, Silva AG, Penchel Filho RM, Reis EF, Ramos KA. Disponibilidade hídrica e doses de polímero hidrorretentor na produção de mudas clonais de eucalipto. Revista Engenharia na Agricultura. 2019;27(4):359-369. doi: 10.13083/ reveng.v27i4.938

\title{
ERRATA
}

No ARTIGo “INFLUENCE OF NITRATES, PHOSPHATE, SULPHATE AND SALTS OF CA, MG AND K, ON HYDROGEL HYDRATATION CAPACITY.”, COM NÚMERO DE DOI : 10.1590/1806-908820200000008, PUBLICADO NO VOLUME 44, DA REVISTA ÁrVORE, ONDE SE LÊ:

\author{
Orlando Sílvio Caires Neves2* ， Igor Glaeser da Rocha3 ，Eduarda Demari Avrella4 , \\ Luciana Paim Pinto4 and Claudimar Sidnei Fior 5
}

L eia-s e:

Orlando Sílvio Caires Neves2* ， Igor Glaeser da Rocha3 ， Eduarda Demari Avrella4 Luciana Pinto Paim 4 and Claudimar Sidnei Fior 5

Revista Árvore 2020;44:e4408 